\title{
Effect of Fermentation with Rumen Content on the Feeding Value of Boiled Iron Tree (Prosopis africana) Seedcoat on Haematology and Serum Biochemistry of Broiler Chickens
}

\author{
B. Bishop ${ }^{a^{*}}$, F. B. P. Abang ${ }^{a}$ and S. Attah ${ }^{a}$ \\ ${ }^{a}$ Department of Animal Production, College of Animal Science, University of Agriculture, Makurdi, \\ Benue State, Nigeria. \\ Authors' contributions
}

This work was carried out in collaboration among all authors. Author BB managed the literature searches, performed the statistical analysis, managed the analyses of the study and wrote the protocol and wrote the first draft of the manuscript. Author FBPA designed the study. All authors read and approved the final manuscript.

Article Information

DOI: $10.9734 / A R R B / 2021 / v 36 i 1230464$
Editor(s):
(1) Dr. Paola Angelini, University of Perugia, Italy.
Reviewers:

(1) Gaffar Sarwar Zaman, King Khalid University, Saudi Arabia. (2) Madhukar Saxena, Babasaheb Bhimrao Ambedkar University, India. (3) S. Sengottuvelu, Dr. MGR Medical University, Tamil Nadu, India. Complete Peer review History: https://www.sdiarticle5.com/review-history/75699

Original Research Article

Received 10 August 2021 Accepted 30 September 2021 Published 15 December 2021

\section{ABSTRACT}

Aims: The study was conducted to evaluate the effect of inclusion of Prosopis seed coat fermented with rumen content at different levels as energy source on the serum biochemical composition and heamatological indices of broiler chickens.

Study Design:Data collected were subjected to analysis of variance in a completely randomized design.

Place and Duration of Study: The study was conducted at the Livestock Teaching and Research Farm of the University of Agriculture Makurdi, Benue State, Nigeria. Between November 2016 and January 2017.

Methodology: The study was in two phases; the starter and finisher phase, in each of the phases, there were five dietary groups and fermented Prosopis africana seed coat meal (FPASCM) was 
included at $0,10,15,20$ and $25 \%$ to replace maize. The total of two hundred and sixty (260), dayold Zartech broiler chicks were randomly distributed to five dietary treatments with four replicates of 52 chickens per treatment and each replicate had 13 birds. The birds were raised on deep litter and fed ad-libitum and drinking water provided daily and performance was monitored. At the end of the eight week, blood was collected via the wing web for serum and haematological assay.

Results: The results of haematological parameters of broiler chickens fed varying levels of fermented Prosopis africana seed coat are presented in Table 3.There were no significant $(P>0.05)$ differences between treatments for parameters measured except for PCV and haemogobin. The PCV values ranged from $25.00-28.25 \%$ and haemoglobin values ranged from $8.35-9.40 \mathrm{~g} / \mathrm{dl}$. It was observed that most of the haematological indices measured fell within the normal reference range values. The results of serum biochemical assay revealed that serum glucose $45.85-107.22 \mathrm{mg} / \mathrm{dl}$ varied significantly $(\mathrm{P}<0.05)$ among the dietary treatments. Birds served $25 \%$ FPSCM had the highest value while those served $15 \%$ FPASCM recorded least value.

Conclusion: Based on the observations from this study, it was concluded that FPASCM could be included in the diets of broiler chickens up to $25 \%$ without compromising the health of the birds.

Keywords: Broiler chickens; Haematology; FPACM and Serum Biochemistry.

\section{INTRODUCTION}

The footprint of animal protein in the diet of the average Nigerian is very low. The repercussions of this include stunted physical and mental growth of children and a stunted productivity of the populace. This, unfortunately, is common to the developing world, Nigeria inclusive. The production and productivity of poultry in the tropics has been limited by high prices of animal feeds, which result from high costs of the conventional protein and energy feed ingredients such as maize, soya bean, wheat, and guinea corn [1]. The high cost of these conventional ingredients partly emanates from the competitive demand from the human food industry. Since feed constitute $60-80 \%$ of the total cost of production, it is very important to identify and bring into use feed resources that are not subject to competition from the human food industry. This will increase the profitability of livestock production, by reducing feed cost, leading to higher productivity, lower animal product prices and higher animal protein consumption by the general populace.

Prosopis africana is a leguminous tree and one of the 44 species of the genus Prosopis. It is abundant in the derived savanna and Sahel regions of tropical Africa [2]. In Nigeria Prosopis seeds are used for making food seasoning, called Okpehe(Idoma), Gbaaye(Tiv), and Kiriya(Hausa)in the middle belt and northern parts of Nigeria, with the empty fruit pods and seed coats forming the major waste products of the process. A lot of researchers have exploited these waste products to the advantage of livestock production.
The study is designed to investigate the effect of fermentation on boiled iron tree (Prosopisafricana) seed coat with rumen content as energy source on haematological and serum biochemical indices of broiler chickens.

Prosopis seed coat is a waste material that is thrown away in a large quantity producing area like Benue state of Nigeria, this can be used extensively, and will therefore, be much cheaper than ingredients such as maize, millet, guinea corn. A few researchers, [3-4] have used prosopis seed coat meal on chickens and quails without deleterious effect. If it could be utilized as source of nutrients by broiler chicken, the result will be, cheaper feeds, lower animal product prices and an improvement in the consumption of table meat by the poorer segments of the human population. The result of this will be higher developmental and productivity indices for the people.

\section{MATERIALS AND METHODS}

\subsection{Nutrients Composition of the Experimental Broiler Starter Diet}

The result of the proximate composition of starter diets is presented in Table 1. The result revealed that crude protein ranged from $21.56-22.13 \%$. The crude protein level was within the recommended level for broiler starter by Aduku [5]. The result of crude fibre ranged from 3.12$4.32 \%$. It was within the required values recommended for broiler starter. The value for 
Ether extract 3.26-4.15 was within the range recommended level by Aduku [5].

\subsection{Nutrients Composition of the Experimental Broiler Finisher Diet}

The result of the proximate composition of broiler finisher diet is presented in Table 2. The result revealed that the crude protein (CP) ranged from $18.05-19.68 \%$. The crude protein was within the recommended level for finisher broiler [5]. The crude fibre (CF) ranged from 2.67-4.24\%. The result of CF was within the required range recommended for finisher diet [5]. Ether extract (EE) ranged from 2.54-4.02. It was observed that the $E E$ reduced as inclusion progresses.

\subsection{Blood Profile of Birds Fed Fermented Prosopis africana Seed Coat Meal}

The results of haematological parameters of broiler chickens fed varying levels of fermented Prosopis africana seed coat are presented in Table 3. There were no significant $(P=.05)$ differences between treatments for parameters measured except for PCV and haemogobin. The PCV values ranged from $25.00-28.25 \%$ and haemoglobin values ranged from $8.35-9.40 \mathrm{~g} / \mathrm{dl}$.
It is observed that most of the haematological indices measured fell within the normal reference range values.

\subsection{Serum Biochemistry of Birds Fed Fermented Prosopis africana seed Coat Meal}

The results of serum biochemical assay of broiler chicken fed graded levels of seed coat diet are presented in Table 4. Results revealed that serum glucose 45.85-107.22 $\mathrm{mg} / \mathrm{dl}$ varied significantly $(\mathrm{P}<.05)$ among the dietary treatments. Birds served 25\% FPSCM had the highest value while those on served $15 \%$ FPASCM recorded the least value.

\section{RESULTS AND DISCUSSION}

The results of haematological parameters of broiler chicken fed varying levels of fermented Prosopis africana seed coat are presented in Table 3. There were no significant $(P>0.05)$ differences between treatments for parameters measured except for Packed cell volume and Haemogobin. The Haemoglobin was significantly $(P=.05)$ affected by the dietary treatments it ranged between $8.35-9.40 \mathrm{~g} / \mathrm{dL}$.

Table 1. Energy and proximate composition of the experimental broiler starter diets

\begin{tabular}{|c|c|c|c|c|c|}
\hline Nutrient & FPASCM T $_{1}(0 \%)$ & $\mathrm{T}_{2}(10 \%)$ & $\mathrm{T}_{3}(15 \%)$ & $\mathrm{T}_{4}(20 \%)$ & $T_{5}(25 \%)$ \\
\hline Crude protein (\%) & 22.13 & 21.89 & 22.04 & 21.56 & 22.13 \\
\hline Crude fibre (\%) & 3.12 & 3.56 & 3.71 & 4.23 & 5.13 \\
\hline Ether extract (\%) & 4.15 & 3.86 & 3.49 & 3.26 & 3.19 \\
\hline Ash (\%) & 3.81 & 4.01 & 4.10 & 4.61 & 5.02 \\
\hline NFE (\%) & 66.79 & 66.68 & 66.66 & 66.34 & 64.53 \\
\hline ME (Kcal/kg) & 3526.43 & 3490.12 & 3464.95 & 3417.18 & 3368.34 \\
\hline
\end{tabular}

Table 2. Energy and proximate composition of the experimental broiler finisher diets

\begin{tabular}{|c|c|c|c|c|c|}
\hline Nutrient & FPASCM T $_{1}(0 \%)$ & $\mathrm{T}_{2}(10 \%)$ & $\mathrm{T}_{3}(15 \%)$ & $\mathrm{T}_{4}(20 \%)$ & $\mathrm{T}_{5}(25 \%)$ \\
\hline Crude protein (\%) & 19.68 & 19.05 & 18.05 & 18.65 & 18.50 \\
\hline Crude fibre (\%) & 2.67 & 3.23 & 3.04 & 3.47 & 4.24 \\
\hline Ether extract (\%) & 4.02 & 3.85 & 3.51 & 3.20 & 2.54 \\
\hline Ash (\%) & 3.31 & 3.84 & 3.69 & 4.05 & 4.33 \\
\hline NFE (\%) & 70.32 & 70.03 & 71.71 & 70.63 & 70.39 \\
\hline ME (Kcal/kg) & 3550.54 & 3503.16 & 3498.22 & 3456.94 & 3389.34 \\
\hline
\end{tabular}


Table 3. Haematological indices of broiler chickens fed diets containing varying levels of prosopisafricana seed coat meal

\begin{tabular}{|c|c|c|c|c|c|c|}
\hline Parameter & FPASCM T $_{1}(0 \%)$ & $\mathrm{T}_{2}(10 \%)$ & $\mathrm{T}_{3}(15 \%)$ & $\mathrm{T}_{4}(20 \%)$ & $\mathrm{T}_{5}(25 \%)$ & P-Value \\
\hline Haemoglobin (g/dL) & $9.18^{\mathrm{a}}$ & $9.40^{\mathrm{a}}$ & $8.98^{\mathrm{a}}$ & $8.35^{\mathrm{ab}}$ & $8.93^{b}$ & $.05^{*}$ \\
\hline Red blood cell $\left(\times 10^{12} / \mathrm{L}\right)$ & 2.50 & 2.30 & 2.35 & 2.13 & 1.73 & .31 \\
\hline White blood cell $\left(\times 10^{9} / \mathrm{L}\right)$ & 1.90 & 1.75 & 1.75 & 1.98 & 2.13 & .65 \\
\hline Packed cell volume (\%) & $27.50^{\mathrm{a}}$ & $28.00^{\mathrm{a}}$ & $27.00^{a}$ & $25.00^{\mathrm{b}}$ & $28.25^{a}$ & $.001^{*}$ \\
\hline Mean corpuscular volume (FL) & 112.45 & 112.45 & 117.63 & 123.53 & 124.70 & .94 \\
\hline Mean corpuscular haemoglobin $(\mathrm{Pg})$ & 37.50 & 40.03 & 39.10 & 34.70 & 41.63 & .56 \\
\hline $\begin{array}{l}\text { Mean corpuscular haemoglobin } \\
\text { concentration }(\mathrm{g} / \mathrm{dL})\end{array}$ & 33.33 & 33.50 & 35.65 & 33.40 & 33.38 & .51 \\
\hline
\end{tabular}
concentration $(\mathrm{g} / \mathrm{dL})$

\footnotetext{
*: Significant

:means in the same row with different superscripts are significantly $(P<0.05)$ different NS: Not significant

FPASCM= Fermented Prosopisafricana Seed Coat Meal
}

Table 4. Serum biochemical parameters of birds fed diets containing fermented Prosopisafricana seed coat meal

\begin{tabular}{|c|c|c|c|c|c|c|}
\hline Parameters & FPASCM T1(0\%) & $\mathrm{T}_{2}(10 \%)$ & $\mathrm{T}_{3}(15 \%)$ & $\mathrm{T}_{4}(20 \%)$ & $\mathrm{T}_{5}(25 \%)$ & $P$ - Value \\
\hline Albumin (g/dl) & 1.45 & 1.57 & 1.60 & 1.75 & 1.58 & .38 \\
\hline Globulin (g/dl) & 1.88 & 0.43 & 1.55 & 1.18 & 0.75 & .49 \\
\hline Total protein (g/dl) & 3.33 & 2.00 & 3.15 & 2.93 & 2.33 & .55 \\
\hline Glucose (mg/dl) & $82.95^{\mathrm{b}}$ & $95.08^{\mathrm{ab}}$ & 45.85 & $91.65^{\mathrm{b}}$ & $107.22^{a}$ & $.01^{*}$ \\
\hline Cholesterol (mg/dl) & 112.83 & 117.65 & 166.57 & 86.15 & 128.93 & .28 \\
\hline Creatinine (mg/dl) & 1.35 & 1.50 & 1.43 & 1.40 & 1.65 & .98 \\
\hline Urea (mg/dl) & 50.55 & 62.50 & 55.45 & 50.10 & 58.00 & .79 \\
\hline
\end{tabular}

*: Significant

NS: Not significant

FPASCM =Fermented Prosopisafricana Seed Coat Meal 
The Red blood cell was not significantly $(P=.05)$ affected by the dietary treatments it was between $1.73-2.50 \times 10^{12} / \mathrm{L}$.

The White blood cell was not significant $(P=.05)$, it ranged between $1.75-2.13 \times 10^{9} / \mathrm{L}$.

The Packed cell volume was significantly $(P<.001)$ affected by the dietary treatments, it ranged between $25.00-28.25 \%$.

Mean corpuscular volume of the birds ranged between $112.45-124.70 \mathrm{FL}$ was not significantly ( $P>0.05)$ affected by the dietary treatment.

Mean corpuscular haemoglobin ranged from 34.70 - $41.63 \mathrm{Pg}$ was not significantly $(P=.05)$ affected by the dietary treatment.

The mean corpuscular haemoglobin concentration was between $33.33-35.65 \mathrm{~g} / \mathrm{dL}$.

\subsection{Serum Biochemistry}

The results of serum biochemistry assay of broiler chicken fed graded levels of seed coat diet are presented in Table 4. Revealed that the serum glucose was significant among the dietary treatment, it ranged $45.85-107.22 \mathrm{mg} / \mathrm{dl}$. Treatment $5(25 \%)$ inclusion had the highest and the lowest was from treatment $3(15 \%)$ inclusion rate.

The albumin was between $1.45-1.75 \mathrm{~g} / \mathrm{dl}$ not significantly $(P=.05)$ affected by the dietary treatments.

The globulin ranged between $0.43-1.88 \mathrm{~g} / \mathrm{dl}$ not significant. Total protein was $2.00-3.33 \mathrm{~g} / \mathrm{dl}$ not significant.

Glucose ranged between $45.85-107.22 \mathrm{mg} / \mathrm{dl}$ was significantly $(P=.05)$ affected by the dietary treatments. Cholesterol level ranged from 86.15 $166.57 \mathrm{mg} / \mathrm{dl}$ not significant.

The creatinine level ranged between 1.35 $1.65 \mathrm{mg} / \mathrm{dl}$ was not significant.

Urea level of the birds ranged between 50.10$62.50 \mathrm{mg} / \mathrm{dl}$ was not significant.

\subsection{Discussion}

The haematological profile of broiler chicken fed PASCM based diets in this study Table 3 showed that the PCV and haemoglobin were significantly $(P=.05)$ influenced by the treatment. The RBC,
WBC, MCV, $\mathrm{MCH}$ and $\mathrm{MCHC}$ did not vary among the treatment groups. The PCV values of 25.00 to $28.25 \%$ recorded in this study fall within the reference range of $22.0-35.0 \%$ as reported by Banerjee [7], $24.90-45.20 \%$ reported by Mitruka and Rawnsley [8] 26.70\% - $45.20 \%$ .reported by Hewitt et al. [9] and $22.00-55.00 \%$ by Terry and Campbell [10]. According to these authors, a PCV of less than $22 \%$ indicates anaemia and one greater than $55 \%$ indicates dehydration. RBC values in this study ranged from $1.73-2.50 \times 10^{12} \mathrm{l}$. This values fall with the range $1.50 \times 10^{12}$ - $3.80 \times 10^{12}$ reported by McDonald et al. [10] for normal chicken. 2.33 $2.66 \times 10^{12} \mathrm{I}$ reported by Terry and Campbell [11] who reported that many factors influences the red blood cell count in birds which include species, age of the birds, sex, hormonal influences, hypoxia, environmental factors and nutritional status. The values of RBC obtained in this study are indication that there was no malnutrition among birds fed experimental diets. Haemoglobin $(\mathrm{Hb})$ values observed in this study ranged from $6.93-9.40 \mathrm{~g} / \mathrm{dl}$ which is within the range of $7.40 \mathrm{~g} / \mathrm{dl}$ to 13.10 for normal healthy birds [8]. $7.0-13.0 \mathrm{~g} / \mathrm{dl}$ reported by Banerjee [7] and $88.9-13.5 \mathrm{~g} / \mathrm{dl}$ reported by Terry and Campbell [10]. This result suggests that the inclusion of PASCM with maize in broiler chicken diets did not affect nutrients availability to bring about protein and iron deficiency and hence causing anaemia. The WBC ranged from 1.75 $2.13 \times 10^{9} \mathrm{I}$, this value is lower than the value of $15.00-30.00 \times 10^{9}$ I reported by Ganti [12]. According to this author, a white blood cell less than $15 \times 10^{9}$ indicates leukopenia, and the one greater than $30 \times 10^{9} \mathrm{l}$ indicates leukocytosis. This implies that the birds of this present studies could be leukopenia or related problems but there was no symptoms or signs among birds. The major functions of the WBC and its differential counts are to fight infections, defend the body by phagocytosis against infection by foreign organisms and to produce or at least transport and distribute antibodies in immune response. The MCV values 112.45 - 124.70fl are comparable with the normal reference values 102.00 - 139.00fl reported by Mitruka and Rawnsley [8] MCV are important in determining the morphological characteristics of anaemic cells [13]. The $\mathrm{MCH}$ values recorded in this study varied from $34.70-41.63 \mathrm{fl}$ which are comparable with the normal reference values of $31.90 \mathrm{pg}-$ $40.50 \mathrm{pg}$ and fall within 33.00-47.00pg as reported by Mitruka and Rawnsley [10] and Jain [14], respectively for healthy birds, 33-47pg reported by Rick [15]. According to Rick, the 
erythrocyte parameters are measurement used to characterize anaemia. The $\mathrm{MCHC}$ values in this study occurred between $3.33-35.65$ which is within the normal reference values of 25.90 $\mathrm{g} / \mathrm{dl}-33.90 \mathrm{~g} / \mathrm{dl}$ for normal chicken as reported by Mitruka and Rawnsley [8] and $26.0 \mathrm{~g} / \mathrm{dl}-35.0$ $\mathrm{g} / \mathrm{dl}$ reported by Jain [14]. The value of $\mathrm{MCHC}$ is a measure of the quantity of haemoglobin in each cell and also shows the ratio of weight of haemoglobin to the volume and haemoglobin content together, so that MCHC is mostly normal. $\mathrm{MCHC}$ value decreases only in severe iron deficiency [16]. These three mean corpuscular values are important to determining the morphological characteristics of anaemic cells. The values of erythrocyte indices obtained in this study appeared to be normal, an indication that FPASCM based diet were adequate in protein, vitamins and minerals including irons. Adequate iron with good quality protein is essential for the formation and maintenance of RBC and prevention of anaemia. The non-significance of most of the parameters investigated in this study agreed with the report of Anonymous [17] who indicated that the non-significance of most haematological and corpuscular indices, erythrocytic and differential counts are indications that the experimental birds were not adversely affected by the dietary treatments.

\subsection{Serum Biochemical Indices}

The serum biochemical indices determine in this study Table 4 showed that only glucose was affected by the dietary treatments while the other indices were not influenced. This result is in harmony with the report of Romeo [18] who indicated that prosopis pod meal had no effect on biochemical indices of broiler chickens. The total protein level in this study varied from 2.33-3.33 $\mathrm{g} / \mathrm{dl}$ reported Adeyemo [19]. Iyaji and Tewe [20] reported that the total serum protein level depends on both quality and quantity of protein supplied in the diets. Globulin values obtained in this study range from $0.43-1.88 \mathrm{~g} / \mathrm{dl}$ which is lower than $33.35 \mathrm{~g} / \mathrm{dl}$ as normal range reported by Ganti [12]. According to the author, an elevated globulin concentration (hyperglobulinaemia) indicates immune stimulation or chronic inflammation with increased globulin product. On the other hand, a low globulin concentration (hypoglobulinaemia) indicates low immunoglobulin concentration and can be caused by conditions such as haemorrhage, protein-loosing gastro enteropathy, immune suppression, immunodeficiency syndrome and severe malnutrition. The serum cholesterol level of 86.15-166.57 g/dl was within the normal reference value (52.00-146 g/dl) [8]. Birds of this study showed high level of cholesterol. This result was in line with the report of Idowu et al. [21] who observed that dietary fibre binds with fat and its associates and therefore reduce their assimilation and further deposition in the tissues, organs and products. Madubuike and Ekenyem [22] reported that elevated level of cholesterol is an indication of higher than desired level of saturated fats in the diets. It was observed that only glucose was influenced by dietary treatments. The range of values (45.85 $107.22 \mathrm{mg} / \mathrm{dl})$ for glucose was lower than 200 $230 \mathrm{mg} / \mathrm{dl}$ recommended as the optimum glucose level in avian species [23]. However, birds did not show any sign of disease that may be associated with energy inadequacy. Malik et al. [16] have opined that the non-significance for most of these parameters is an indication of good liver functioning when high fibre diets are used in poultry nutrition. Aside some genetical factors observed in birds, PASCM is an energy and fibre source in poultry diets, its inclusion in the diet in this study seems to enhance the haematological and biochemical characteristics of broiler chickens. This findings is similar to the result obtained by Schley and Field [24]; Kwariet al. [25] and Malik et al. [16] who observed that the different energy sources have no negative effect on serum biochemical indices of avian species. The albumin values ranged from $1.45-1.75 \mathrm{~g} / \mathrm{dl}$, it is within the range $1.17-2.74 \mathrm{~g} / \mathrm{dl}$. A higher concentration of albumen usually denotes dehydration while a lower concentration may be due to the liver not functioning adequately due to factors such as malnutrition and infection. [26]. Albumin is a protein serum is synthesized in the liver, it is responsible for transporting insoluble substance in the blood and aids to maintain pressure [27]. Hassan et al. [28] suggest that non-significant values for albumin and Globulin in Decorticated fermented Prosopisafricana seed coat meal is a nutritional adequacy of the dietary protein for the treatment. The values for urea ranged from $50.10-62.50 \mathrm{mg} / \mathrm{dl}$ is above the normal range 1.9-12.5 mg/dl reported by Clinical Diagnostic Division [29] for uric acid. A low urea suggests more efficient metabolism proper renal and hepatic function. Age, sex and diet of birds influence the amount of uric acid. A high level of uric acid (hyperuricaemia) is usually evident in female birds due to ovulatory activities. Creatinine values present in the experimental birds range from $1.35-1.65 \mathrm{mg} / \mathrm{dl}$, this is within the range 1.41 reported by Sandhu et al. [30] for 
broilers at 35 days. He stated that younger and older broiler chickens have low levels of blood creatinine. Creatinine is used to determine of the status of the kidney. The functions of the kidney include excretion of waste products resulting from protein metabolism and muscles contraction. High amount of creatinine could also indicate that the kidney is not functioning optimally.

\section{CONCLUSION}

Based on the observations drawn from this study, It is concluded that, FPASCM could be included in the diets of broiler chickens up to $25 \%$ without compromising their health.

\section{ACKNOWLEDGEMENTS}

I am deeply indebted to my supervisors $\mathrm{Dr}$. (Mrs.) F. B. P. Abang and Prof. S. Attah and their amiable families for their encouragements, commitments and untiring efforts in providing the necessary information that enabled the production of this work. My sincere appreciation goes to Prof. O. I. A. Oluremi, Dr G. O Egahi and $\mathrm{Mr}$ I. D. I Yaakugh for genuine and sincere encouragement. My appreciation to my loving and caring husband who has been a great source of encouragement and support, parent and also to my in-laws (the Omananyi's) and the family of Aaron Abu who are always concern about my project. May God Almighty grant everybody long life and prosperity in Jesus name (Amen).

My thanks goes to the family of Prof.P. Onimisi, ABU Zaria, my brothers Stephen and Jeremiah for their tremendous effort during the period of this study.

A friend in need is a friend indeed, I am not forgetting to thank my good friends namely Rose Yakubu, Helen Arziki, Salamatu Musa, Titus Annongo, just to mention but a few for their enormous assistance. Same also to my children Gloria and Gideon.

\section{COMPETING INTERESTS}

Authors have declared that no competing interests exist.

\section{REFERENCES}

1. Atawodi SE, Mari D, Atawodi JC, Yahaya Y. Assessment of Leukaemia leucocephalleaves as feed supplement in laying hens. African Journal Biotechnology. 2008;7:317- 321.

2. Keay RWJ. Trees of Nigeria, Clarendon press, Oxford, UK; 1989.

3. Adeyi MO, Abang FBP, Attah S. Performance of broiler chickens fed diets containing graded levels of boiled Prosopisafricanaseed coat meal treated with multi-enzymes. Journal of Science and Technology and Education. 2021;9(1):206-210.

4. Odeh MO, Attah S, Abang FBP. Performance and Carcass Characteristics of Layer Chickens Fed Diets containing Prosopisafricana seed coat meal treated with polyenyme. International Journal of Environment, Agriculture and Biotecnology. 2019;4(6):1750-1757.

5. Aduku AO. Animal Nutrition in the tropics: Feed and Feeding, Pasture Management, Monogastrics and Ruminants Nutrition. $1^{\text {st }}$ ed. University Press. ABU, Zaria, Nigeria; 2004.

6. Pauzenaga U. Feeding parent Stock. Zootech. International. 1985;22-25.

7. Banerjee GC. A Text book of Animal Husbandary, 8thed.New Delhi, Oxford and IBH Publishing Co. PVT Ltd. 2004;118138.

8. Mitruka BM, and Rawnsley HM. Clinical and biochemical haematological reference values in normal experimental animal. Manson publishing Company, New York. 1977;231-245.

9. Hewitt CD, Innes DJ, Sarory J. and Willis MR. Normal biochemical and haematology Values for New Zealand White. rabbits. Clinical Chemistry. 1989;35(8):17771779.

10. Terry W, Campbell MS. Avian haematology and cytology, 1st ed. lowa State University press, Ames. 1988;5-13.

11. McDonald $\mathrm{P}$, Edwards RA, Greenhalgh JFD, and Morgan CA. Animal Nutrition, $5^{\text {th }}$ edition ( $3^{\text {rd }}$ report). Longman Scientific and Technical publishers. 1998;607.

12. Ganti, AS. Veterinary Clinical Pathology, CBS Publishers and Distributors. New DelhiBangolore, Pune. (India). $3^{\text {rd }}$ ed. 2009;200.

13. Cambell TW. Avian haematology and cytology. lowa State University Press/Ames. 1998;248.

14. Jain NC. Schalm's Veterinary Haematology, $4^{\text {th }}$ Ed. Philadelphia, USA, lea and Fabiger. 1986;34-50. 
15. Rick LC. Veterinary Clinical Pathology Secrets, Elsevier ink. $1^{\text {st }}$ ed. 2004;150.

16. Malik AA, Kudu YS, Gold RO. Haematology, Serum Biochemistry and Economic Characteristics of cockerels fed diets containing Varying levels of Water Hyacith [Eichlorniacrassipes (mart.) solms-Laubach] meal supplemented with maxigrain $R$ enzyme. Nigerian Journal of Animal Science. 2018;20(2):241-249.

17. Anonymous. Guide to the care and use of experimental animals, Canadian Council of Animal Care, Ottawa, Ontario, Canada. 1980;(1):85-90.

Accessed 30 January, 2017. Available: http://www.sciepub.com>refererence.

18. Romeo AC. Effect of prosopisafricana Pod Meal fermented with rumen content on serum biochemical indices of broiler finishers. B. Agriculture., Federal University of Agriculture, Makurdi, Benue State, Nigeria. 2016;71. (In press).

19. Adeyemo GO. Effect of Cottonseed cake based diets on haematology and serum biochemistry of egg-type chickens. International Journal of Poultry Science. 2008;7(1):23-27.

20. Iyaji $E A$, Tewe OO. Serum total protein, urea and creatinine levels as indices of quality of cassava diets for pigs. Journal of Tropical Veterinarian. 1998;8:11-15.

21. Idowu OMO. Effect of unpeeled cassava based diets on performance and cholesterol level in laying hens. Ph.D. Thesis, Department of Animal Nutrition, University of Agricultural, Abeokuta, Ogun State, Nigeria. 2004;186. (In press).

22. Madubuike FN, Ekenyem BU. Haematology and Serum Biochemistry characteristics of broiler chicks fed varying levels of Ipomeaasarifolia leaf meal. International Journal of Poultry Science. 2006;5:9-12.
23. Olomu JM. Monogastric Animal Nutrition, Principle and Practices. Second Edition. Benin City, Nigeria. St, Jackson Publishers. 2011;478.

24. Schley PD, and Field CJ. The immune enhancing effects of dietary fibres and probiotics. British Journal of Nutrition. 2002;87(2):221-230.

25. Kwari ID, Igwebuike JU, Taiya $H$, Muhaamad AA, Raji AO. Haematology and seriology of chickens fed maize, sorghum and millet, and their combination in the semi-arid zone of Nigeria. International Journal of Science and Nature. 2014;5(2):319-322.

26. Esubonteng PKA An assessment of the effect of moringaolifera leaf powder as a nutritional supplement in the diet. Kumasi: Kwame Nkruma University of Science and Technology. In press; 2011.

27. Fischbach FT, Dunning MB. A Manual of laboratory and diagnostic tests. Philadelphia: Lippi; 2009.

28. Hassan D, Yusuf N, Musa M, Musa Azara I, Barde R, Ogah D, Yakubu A, Ari M. Haematology and some serum parameters of broilers fed decorticated fermented prosopisafricanaseed meal. Journal for Agricultural Science and Technology. 2014;6(2):170-174.

29. Clinical Diagnostic Division.Vetenary reference guide: a summary of reference intervals for use with KODALEKTACHEM Products. Rochester (NY). Eastman Kodak Company; 1990.

30. Sandhu BS, Singh B, and BrarRS. Haematology and biochemical studies in broiler chickens fed ochratoxin and inoculated with inclusion body hepatitis virus, singly and in concurrence. Veternary Research Communications.1998;22:335346.

(0) 2021 Bishop et al.; This is an Open Access article distributed under the terms of the Creative Commons Attribution License (http://creativecommons.org/licenses/by/4.0), which permits unrestricted use, distribution, and reproduction in any medium, provided the original work is properly cited.

Peer-review history:

The peer review history for this paper can be accessed here: https://www.sdiarticle5.com/review-history/75699 